\title{
On the Combination of Sports Spirit and Socialist Core Values
}

\author{
Xiaobo Yang, Qing Li \\ Nanchang Institute of Science \&Technology, Nanchang 330108, China
}

\begin{abstract}
This paper focuses on study the association "win glory for the motherland, selfless dedication, scientific truth-seeking, law-abiding, solidarity, hard struggle" sports spirit and prosperity democracy 、 civility 、 harmony freedom、 equality、 justice、 the rule of law patriotism、 dedication、 integrity friendship of socialist core values. Sports spirit and the socialist core values of the same essential requirements; Sports spirit and the socialist core values got the consistency goal. Study on the sports spirit, especially the spirit of sports unique nature features and charm, plays a social phenomenon the irreplaceable role in the cultivation of socialist core values, it has realistic significance to enrich the connotation of socialist core values.

Keywords: Sports Humanitiest; Sports Spirit; Socialist Core Values
\end{abstract}

\section{Introduction}

The Eighteenth National Congress of the CPC put forward, advocating prosperity democracy civility 、 harmony freedom、 equality justice、 the rule of law 、 patriotism、dedication 、integrity 、 friendship, actively cultivate and practice the core socialistvalues. In the sports practice of the Chinese nation, and gradually formed a win glory for the motherland, selfless dedication, scientific truth-seeking, law-abiding, unity and cooperation, hard work as the main content of the Chinese sports spirit, has important significance to cultivate and practice the socialist core values. 


\section{The connotation of Chinese sports spirit}

Back in history, 1981, China women's volleyball team took the first World Cup, the whole nation is exciting. Subsequently, women's volleyball team to "hard work, for" faith, made "five". Women's volleyball athletes training hard, win glory for the country, showing the spirit of sports has a huge incentive to all walks of life.

In the Atlanta Olympic Games, China sports delegation to 16 gold scores ranked fourth in the world, after the game, "China sports newspaper" unity, from theory and practice, unity of tradition and reality sports unique and universal social unity three aspects of research and analysis, introduced the country first dedication science realistic law-abidingsolidarity hard work, six article systematically discusses the Chinese sports spirit reports. The Chinese sports spirit is an important part of China's socialist spiritual civilization, is the precious wealth of the Chinese nation, various industries, all fronts in the country comrades must vigorously carry forward the rejuvenation of the Chinese nation, for the spirit of patriotism, vigorously carry forward the indomitable top-notch spirit of revolutionary heroism, innovation, ability to climb the peak of one heart and one mind. Push forward the great cause of building socialism with Chinese characteristics.

With the continuous development of the times, Chinese sports people in the years of practice, summed up that the glory of the country, selfless dedication, scientific truth-seeking, law-abiding, unity and cooperation, hard work is the main content of the Chinese sports spirit, Chinese sports spirit has become the common spiritual wealth of the whole society. In August 31, 2013, the Twelfth National Games opening ceremony, general secretary $\mathrm{Xi}$ Jinping met to participate in the national mass sports advanced units and advanced individuals in recognition, emphasizing the national sports system advanced collective and advanced workers commended the will on behalf of the Chinese sports spirit, not easily won, precious, to inherit, carry forward innovation.

\section{Sports spirit and socialist core values got the same requirements}

Chinese sports spirit as the ideological core and the fundamental driving force for development, is an important content of advanced culture in China, is an important carrier of socialist ideological and moral construction, embodies the spirit of patriotism. Since the establishment of China's sports, who work hard, forming a fine style of be handed down from age to age, tenacious struggle and glory for the country. According to the actual physical education and social development, to win glory for the country as the core of the Chinese sports spirit, is an important part of the great rejuvenation of the Chinese nation spirit, in the rapid economic and social development background, to be given a clear sense of the times. 
Dedication embodies the sense of social responsibility, is the spiritual pillar of the Chinese nation, the yearning of the Chinese nation. For individuals, not only reflects a person's attitude towards life, but also reflects a person's moral and moral behavior. Many scholars at all times and in all countries respected selfless thought. Selfless dedication is the highest level of dedication, is the highest realm of virtue. Selfless dedication is the inevitable requirement of social existence and development, is a high degree of moral self-discipline, is the specific manifestation of altruistic behavior.

Carry forward the spirit of scientific and realistic elements is the spirit of China's sports front since the reform and opening up, new connotation is the spirit of the Chinese nation. I believe that science, relying on science, seeking truth from facts, breaking the dogma, pioneering and innovative, not only the work style of competitive sports, but also the need to implement the principles of all walks of life. Great achievements have been made in China's sports industry and the spirit of scientific, realistic and pioneering spirit of Chinese sports workers. The real core technology, the key technology is not to buy, we must rely on independent innovation. In the field of sports, science and innovation is a magic weapon for winning the competition, the fundamental reason Chinese table tennis prosperous is to adhere to the scientific training, continuous innovation, and gradually formed, qinxuekulian, refuse to be cowed or submit into a continuous, innovative spirit of table tennis.

In the sports arena, the athletes should obey the discipline of sports training, in strict accordance with the protocol, and even in daily life should be subject to strict constraints. In the competition, we must strictly abide by the rules of competition, respect all personnel at home and abroad. Obey the law also embodies the fair competition in the occupation moral. At present, the socialist market economy is the economic equity and credit economy, in the process of development, to vigorously carry forward the spirit of fair play Chinese athletes law-abiding, consciously abide by the order of the market and competition rules, and jointly safeguard the orderly operation of the socialist market economy.

\section{Sports spirit and socialist core values got the consistency goal}

The practice of sports spirit, is the motherland first for sports spirit into practice, to create a good sports culture atmosphere, enhance cultural soft power of the Chinese nation, and strive to promote all-round development of China's economy, politics, culture and society, to improve our country's comprehensive strength of purpose. Practice the socialist core values, through theory of belief education and patriotism education, cultivate national people's prosperity 、 democracy 、 civility 、 harmony at the national level, value orientation, firm road, actively practice, promote the development of the socialist cause China characteristics, contribute to the formation of vivid situation of prosperous economy and democratic politics, civilization and harmonious society. 
It can be seen that both sports spirit and socialist core values focus on economic, political, cultural and social development, pay attention to the spirit of patriotism.

The practice of sports spirit in sports practice, to the law as the criterion, in order to build a harmonious social environment as the goal, and actively cultivate the free and fair competition, and mutual respect, equality and justice of the concept of the rule of law. As a part of civil society ethics, law-abiding in sports performance is to strictly abide by the rules of sports competition, respect the opponent, the referee and the audience, with sports ethics, do justice and the rule of law in sports and sports management, embody the equality and freedom. Practice the socialist core values, through legal education, law education and national unity and progress of education to cultivate people's national freedom, equality, justice, rule of law and the social value orientation, adhere to the Marx doctrine of equality, adhere to social fairness and justice, uphold the rule of innovation, fostering good social mentality, and strive to build a harmonious social environment .

Therefore, the development of sports spirit and the socialist core values both focus on harmonious society and law-abiding.

The practice of sports spirit, to cultivate a good social morality, occupation morality, family virtue and individual character as the goal, and actively practice the selfless dedication, scientific truth-seeking, unity and cooperation and indomitable spirit; practice the socialist core values, and actively guide the people ethical, moral respect, moral cultivation, value criterion of national level of patriotism, dedication honest and friendly, to form a source of power.

In practice, Our country sports people focus on inheritance and innovation, not complacent also not imitate others, scientific objectivity, tenacious struggle, mastered the magic weapon volleyball, table tennis, diving, gymnastics and other projects. This is our sports people follow the scientific spirit is inseparable, and it puts forward the socialist core values dedicated consistent requirements to work should be treated with respect, enterprising spirit and pragmatic attitude, respect the objective facts.

\section{The spirit of sports and socialist core values got the same development path}

The spirit of sports reflects the positive enterprising spirit of human being's pursuit of progress, love of peace, efforts to go up and beyond the limit. Since the new China established, generations of athletes and sports workers formed the extremely hard and bitter struggle, patriotism, heroism, optimism, fair competition, collectivism, realistic science and the spirit of selfless dedication, is the precious spiritual wealth of the Chinese nation. In the different historical periods of China's modernization construction, it has strengthened the cohesion and centripetal force of the whole nation again and again, and has not been able to develop the spirit of self-reliance and self-confidence of the Chinese nation to 
the whole world. In a certain sense, the Chinese sports spirit is an organic part of the socialist core values, but also an important manifestation of the socialist core values in the practice of sports. Analysis from the national level, social level and individual leve, Chinese sports spirit and the socialist core values essence and development path is completely consistent. The spirit of sports promotes the development of economy, politics, culture and society. Sports has become an indispensable part of people's lives, sports to promote economic growth of countries or regions the role is self-evident, the world for hosting the world games, the fancy is the sports on the national or regional economic development role. The development of physical education has a promoting effect on the status of the nation in the world. The influence of the physical and cultural soft power on the country or region is also profound education as a major industry development, to build a large modern stadium, to create a good sports culture environment, to promote the harmonious development of society.

Along with the socialist market economy increases, an important sign of sports has become a country or region's social development and the progress of civilization, the level of development of sports industry has become an important manifestation of the comprehensive strength and social civilization of the country or region. Along with the development of competitive sports and national sports physical fitness, people increasingly strong desire, the position of sports has become more and more important, the importance of the development of sports spirit of human society are more prominent, especially in the spirit of the people of the mold and casting, to carry forward and cultivate socialist core values. The Chinese sports spirit has a unique contribution to the cultivation and practice of the socialist core values, especially the unique function and charm of the sports is the substitution of other social phenomena or things. This unique feature is its highlight the unremitting self-improvement, not afraid of setbacks, the courage to struggle, dare to win, beyond the self, self-esteem, optimism, fair competition, rule consciousness, innovation, respect for individuality, development differences, common development, respect for science, the spirit of seeking truth from facts, are an important part of the practice of the core socialist value.

Sports not only enrich people's entertainment life, but also the screen on the network and occupy half of the country, widely makes the sports spirit strong radiation vector. The sports itself is a good carrier of moral education, from unity to respect the opponent, respect the referee and respect the audience have the elements of moral education, sports spirit, the spirit of heroism, optimism and rich spirit of patriotism, the spirit of fair competition, team spirit, practical rational spirit, which plays a positive role in promoting the practice of socialist core values.

\section{Conclusion}

Sports spirit has profound ideological origin and rich spiritual connotation, and practicingsports spirit plays an important role in consolidating the ideological foundation of the socialist core values and grasping the essential requirements. 
The essential function of sports spirit and unique charm, especially in the current rapid development of competitive sports and national fitness movement environment, play other social activities irreplaceable role in the cultivation of socialist core values. The sports spirit in essence, practice target and development path are associated with natural, sports spirit, has practical significance to research enrich the connotation of socialist core values.

\section{References:}

[1] Zhang B, University H N. On the Fitness of Leifeng Spirit and the Socialist Core Values[J]. Guide of Science \& Education, 2014.

[2] Yang S L. On the Function of Lei Feng Spirit in the Construction of Socialist Core Value System[J]. Journal of Changchun Normal University, 2012.

[3] Lin L. Education of Socialist Core Value System Based on Lei Feng Spirit[J]. China Education of Light Industry, 2013.

[4] Qin Z W. Yimeng Spirit and the Socialist Core Values System[J]. Journal of Linyi University, 2015.

[5]Kang F Y, Zhang Y L. Essential Connotation and Time Value of Lei Feng Spirit[J]. Journal of Wuhan Textile University, 2012. 